OPEN ACCESS

Edited by:

David Georges Biron,

Centre National de la Recherche

Scientifique (CNRS), France

Reviewed by:

Daniela Campobello,

University of Palermo, Italy

Fleur Ponton,

Macquarie University, Australia

*Correspondence:

Ida Beitnes Johansen

ida.johansen@nmbu.no

Specialty section:

This article was submitted to Behavioral and Evolutionary Ecology,

a section of the journal

Frontiers in Ecology and Evolution

Received: 10 September 2018 Accepted: 11 February 2019

Published: 06 March 2019

Citation:

Øverli Ø and Johansen IB (2019) Kindness to the Final Host and Vice Versa: A Trend for Parasites Providing

Easy Prey? Front. Ecol. Evol. 7:50.

doi: 10.3389/fevo.2019.00050

\section{Kindness to the Final Host and Vice Versa: A Trend for Parasites Providing Easy Prey?}

\author{
Øyvind Øverli and Ida Beitnes Johansen*
}

Department of Food Safety and Infection Biology, Faculty of Veterinary Medicine, Norwegian University of Life Sciences, Oslo, Norway

Traditionally the "extended phenotype" concept refers to parasites that manipulate host phenotype to increase parasite fitness. This includes parasites that render intermediate hosts more susceptible to predation by final hosts. We explore here the proposition that an evolutionary driver in such cases is the energetic benefit to the final host, in addition to increased parasite fitness. We will review some well-established host-manipulation models, where such a scenario seems likely. One example is provided by the protozoan Toxoplasma gondii, which conspicuously impairs predator avoidance in rodents. Pathologies in humans that acquire T. gondii are known, but infection in adult feline definitive hosts are most commonly asymptomatic and apparently innocuous. In another well-documented case of parasite-mediated trophic transmission, trematode (Euhaplorchis californiensis) infected killifish (Fundulus parvipinnis) abandon normal caution and exhibit a range of behaviors which makes them more conspicuous to predatory birds. The birds get a free meal, but the presence of adult trematodes in the gut would seem to incur few if any negative consequences for the birds. There are exceptions to this pattern also among cases of parasite mediated trophic transmission, but major pathology in definitive hosts seems for the most part restricted to cases where manipulated intermediate hosts are of minor energetic importance. Current theories for the evolution of reduced pathogenicity in predatory final hosts primarily focus on parasites minimizing pathogenicity to increase their own reproductive output and/or avoid selection on host preference for non-infected prey types. Here we advocate another alternative: If or when the benefit of increased prey acquisition outweighs pathogenicity or resource drain, there should be little or no selection on final hosts to minimize parasite infections. This means that not only will host avoidance of infection not develop, but the molecular arms race for increased immunological defense will also likely be halted in such cases.

Keywords: arms race, coevolution, cost-benefit, extended phenotype, immunity, parasite manipulation, trophic transmission

\section{INTRODUCTION: PARASITES AND THE EVOLVING IMMUNE SYSTEM}

Multicellular animals achieve defense against other, disease-causing organisms by means of a range of complex immune responses. Analogously as to how the highly complex vertebrate nervous system evolved from much simpler signaling systems, the immune system evolved from simpler defense mechanisms. The evolutionary mechanisms involved are a topic of intense study 
(Kaufman, 2010; Rich and Chaplin, 2019). This quest reflects the fundamental interest in long-term co-evolutionary arms races between parasites and pathogens and their hosts (Decaestecker et al., 2007; Brockhurst et al., 2014), as well as the need to understand the rapidly developing multitude of immune related diseases in the human population (Dunne and Cooke, 2005; Allen and Maizels, 2011; Levine et al., 2011). For the most part, interest has been directed into how the immune system detects and fights invaders, and how these invaders in turn develop infectivity by avoiding detection and attack (Woolhouse et al., 2002; Paterson et al., 2010; Hall et al., 2011; Laanto et al., 2017). In a majority of studies, focus is placed on the conflict between hosts and their parasites and pathogens, and the resulting evolutionary arms race. In an ecological context, however, roles of different interacting species cannot be strictly limited to the traditional definitions of parasitic or mutualistic (Betts et al., 2016).

Species of parasites, which inhabit and utilize different host species for different purposes during their life cycle, will have contrasting effects on hosts depending on both transmission stage and host as well as parasite developmental stage (Parker et al., 2009; Dianne et al., 2011; Weinreich et al., 2013). Parasites occupying multiple sequential host species appear as appropriate model systems for variable nature of host-parasite relationship. Parasites may be beneficial in certain contexts (Thomas et al., 2000), for instance protecting their hosts from either predation or disease (Methot and Alizon, 2014; Gopko et al., 2015), and recent publications analyze how parasites may evolve to protect their hosts (Ashby and King, 2017). Here we will suggest that the ability of parasites to potentiate host fitness also by indirect extended phenotype effects could be an overlooked but potent evolutionary driver in shaping the host immune response.

We focus in this review on cases of co-existence without fierce resistance, in other words when an organism reside in the body of another species without apparent negative consequences. Understanding the biology behind such conditions could potentially provide clues to combatting over-activation and resulting immunopathologies.

\section{HOST AND PARASITE PERSPECTIVES}

Pinnacles for the evolution and ontogenetic unfolding of virulence and pathogenicity vs. benign interactions has been addressed previously by multiple authors (Ewald, 1987, 1995; May and Anderson, 1990; Anderson and May, 1992; Nowak and May, 1994; Combes, 2001). A parasite infection will generally evoke an immune response in the host, and parasite species with complicated life cycles need to overcome a variety of immune defenses from multiple hosts, often of both vertebrate and invertebrate origin (Auld and Tinsley, 2015). For example, if completion of the life cycle requires sickening or conspicuousness of an intermediate host, but health and longevity of the final host, pathogenicity needs to be adjusted accordingly. To complicate things further, a parasite might have different purposes even in the same host depending on its developmental stage. For example, a parasite awaiting trophic transmission but is not yet infective for its next host, could be expected to minimize damage and seek to extend the life span of an intermediate host. When the parasite matures and becomes infective for the next host, however, its infection mechanism may change with adverse consequences for the host (Parker et al., 2009; Dianne et al., 2011; Weinreich et al., 2013). Thus, parasites may adjust their virulence to match their life history strategy and stage. An example of such a strategy is provided by the cestode Schistocephalus solidus, plerocercoids of which reduce anti-predator behavior of sticklebacks (Gasterosteus aculeatus) only when infective to the final host, piscivorous birds (Tierney et al., 1993).

Parasites may reduce or even enhance longevity and survival of the host depending on what is the most adaptive outcome for them (Hammerschmidt et al., 2009; Dianne et al., 2012). Hosts, in turn will adjust their response to maximize expected life time fitness. Hence, hosts may have very different degrees of incentives for fighting off the parasite and accordingly invest in immunity.

From the perspective of the host, in particular regarding parasites manipulating host phenotype, the evolutionary pressures for parasite resistance may be highly variable (Poulin et al., 1994). In short, a host that suffers from manipulation by the parasite in a way that only benefits the parasite could be expected to develop a strong immune response compared to a host that do not suffer considerably. But even in hosts that do not directly benefit or even that severely suffer from infection, there is a trade-off between keeping the parasite infection in check and avoiding potential immunopatholoical costs and even mortality associated with immune reactivity (i.e., autoimmunity) (Graham et al., 2005; Maizels, 2016). Of note, heavy investment in immune responses obviously also goes at the expense of investment in other imperative traits, such as growth (Soler et al., 2003; Brommer, 2004) and reproduction (Gustafsson et al., 1994; Nordling et al., 1998; Siva-Jothy et al., 1998).

In the following we introduce a hitherto overlooked factor that may limit the immune response of end hosts, namely the energetic/nutritional benefit of prey rendered easily captured because of infections. By now, a multitude of examples have been described where parasite-associated changes in the phenotype of intermediate hosts appear to facilitate trophic transmission. In many cases it would appear that the final host indeed benefits from the presence of a certain parasite, and would gain little from eliminating it. A close scrutiny of current literature reveals few reports of apparent pathology or other negative fitness effects on the end host in such systems (see Table 1).

\section{PARASITES PROVIDING EASY PREY}

Many parasite life cycles include a stage at which successful transmission requires that an infected host must be ingested by a predator, which then becomes host for the next -and often final- life stage of the parasite. Specifically regarding such trophically transmitted parasites, it can be predicted that pathology should be low in the final predatory host, otherwise a negative fitness effect would select for avoidance of parasitized prey (Lafferty, 1992; Kuris, 2003). Scenarios where different hosts in a trophically transmitted life cycle is impacted differently 
TABLE 1 | Parasites providing easy prey.

\begin{tabular}{|c|c|c|}
\hline Genus & Intermediate host, phenotypic change & Parasite effects on final host \\
\hline \multicolumn{3}{|l|}{ ACANTOCEPHALA } \\
\hline Moniliformis moniliformis & $\begin{array}{l}\text { Insecta; Blattidae (Periplaneta americana) } \\
\text { Behavior (Moore, 1983a; Wilson and Edwards, 1986; Libersat and } \\
\text { Moore, 2000) }\end{array}$ & $\begin{array}{l}\text { Mammalia; Muridae (Rattus norvegicus) } \\
\text { Local intestinal histopathological changes (Teimoori et al., 2011). }\end{array}$ \\
\hline $\begin{array}{l}\text { Acanthocephalus } \\
\text { dirus }\end{array}$ & $\begin{array}{l}\text { Crustacea; Isopoda (Caecidotea intermedius, Asellus intermedius) } \\
\text { Behavior and appearance (Camp and Huizinga, 1979; Hechtel et al., } \\
\text { 1993) }\end{array}$ & $\begin{array}{l}\text { Actinopterygii; Cyprinidae (Semotilus atromaculatus) } \\
\text { No reports on S. atromaculatus, but see (Bullock, 1963; Schmidt et al., } \\
\text { 1974; Sakthivel et al., 2016) }\end{array}$ \\
\hline $\begin{array}{l}\text { Acanthocephalus } \\
\text { lucii }\end{array}$ & $\begin{array}{l}\text { Crustacea; Isopoda (Asellus aquaticus) } \\
\text { Behavior, increased predation rate (Benesh et al., 2008) }\end{array}$ & $\begin{array}{l}\text { Actinopterygii; Percidae } \\
\text { No reports on pathology, but see (Sures, 2002) }\end{array}$ \\
\hline $\begin{array}{l}\text { Polymorphus } \\
\text { paradoxus }\end{array}$ & $\begin{array}{l}\text { Crustacea; Amphipoda (Gammarus lacustris) } \\
\text { Behavior, increased predation rate (Holmes and Bethel, 1972; Bethel } \\
\text { and Holmes, 1973, 1977) }\end{array}$ & $\begin{array}{l}\text { Aves and Mammalia } \\
\text { No reports }\end{array}$ \\
\hline Polymorphus laevis & $\begin{array}{l}\text { Crustacea; Amphipoda (Gammarus lacustris) } \\
\text { Behavior, increased predation rate (Bakker et al., 1997) }\end{array}$ & $\begin{array}{l}\text { Actinopterygii; Gasterosteidae (Gasterosteus aculeatus) } \\
\text { Survival cost proportional to severity of infection (Mazzi and Bakker, } \\
\text { 2003) }\end{array}$ \\
\hline $\begin{array}{l}\text { Corynosoma } \\
\text { constrictum }\end{array}$ & $\begin{array}{l}\text { Crustacea; Amphipoda (Hyalella azteca) } \\
\text { Behavior, increased predation rate (Bethel and Holmes, 1973, 1977) }\end{array}$ & $\begin{array}{l}\text { Aves } \\
\text { No reports }\end{array}$ \\
\hline $\begin{array}{l}\text { Plagiorhynchus } \\
\text { cylindraceus }\end{array}$ & $\begin{array}{l}\text { Crustacea; Isopoda (Armadillidium vulgare) } \\
\text { Behavior, increased predation rate (Moore, 1983b) }\end{array}$ & $\begin{array}{l}\text { Aves, Sturnidae (Sturnus vulgaris) } \\
\text { Both reported to be of little or no histopathological consequence } \\
\text { (Moore and Bell, 1983a) and to negatively affect energy metabolism } \\
\text { (Connors and Nickol, 1991). }\end{array}$ \\
\hline Profilicollis spp & $\begin{array}{l}\text { Crustacea; Decapoda (Macrophthalmus hirtipes, Hemigrapsus } \\
\text { crenulatus) } \\
\text { Behavior (Latham and Poulin, 2002) }\end{array}$ & $\begin{array}{l}\text { Aves } \\
\text { Local intestinal damage and inflammation, potentially lethal in young } \\
\text { chicks (La Sala et al., 2013). }\end{array}$ \\
\hline $\begin{array}{l}\text { Pomphorhynchus } \\
\text { laevis }\end{array}$ & $\begin{array}{l}\text { Crustacea; Amphipoda (Gammarus pulex) } \\
\text { Behavior, increased predation rate (Kennedy et al., 1978; Kaldonski } \\
\text { et al., 2007; Dianne et al., 2012) }\end{array}$ & $\begin{array}{l}\text { Actinopterygii } \\
\text { Local intestinal damage and inflammation and reduced condition factor } \\
\text { in Cottus gobio (Sheath, 2016). No effect on growth or mortality in } \\
\text { salmonids (Pippy, 1969; Wanstall et al., 1986) or cyprinidae, } \\
\text { recognized as preferred hosts (Hine and Kennedy, 1974) }\end{array}$ \\
\hline \multicolumn{3}{|l|}{ TREMATODA (DIGENEA) } \\
\hline $\begin{array}{l}\text { Curtuteria } \\
\text { australis }\end{array}$ & $\begin{array}{l}\text { Mollusca; Bivalvia (Austrovenus stutchburyi) } \\
\text { Behavior, increased predation rate (Thomas and Poulin, 1998) }\end{array}$ & $\begin{array}{l}\text { Aves; Haematopodidae (Haematopus palliates) } \\
\text { No reports }\end{array}$ \\
\hline $\begin{array}{l}\text { Euhaplorchis } \\
\text { californiensis }\end{array}$ & $\begin{array}{l}\text { Actinopterygii; Fundulidae (Fundulus californiensis) } \\
\text { Behavior, increased predation rate (Lafferty and Morris, 1996) }\end{array}$ & $\begin{array}{l}\text { Aves } \\
\text { No reports }\end{array}$ \\
\hline $\begin{array}{l}\text { Microphallus } \\
\text { turgidus }\end{array}$ & $\begin{array}{l}\text { Crustacea; Decapoda (Palaemonetes pugio) } \\
\text { Behavior, increased predation rate by non-final host (Kunz and Pung, } \\
\text { 2004; Gonzalez, 2016) }\end{array}$ & $\begin{array}{l}\text { Aves } \\
\text { No reports }\end{array}$ \\
\hline $\begin{array}{l}\text { Brachylecithum } \\
\text { mosquensi }\end{array}$ & $\begin{array}{l}\text { Insecta; Formicidae (Camponotus herculeanus) } \\
\text { Behavior (Carney, 1969) }\end{array}$ & $\begin{array}{l}\text { Aves; Turdidae (Turdus migratorius) } \\
\text { No reports }\end{array}$ \\
\hline $\begin{array}{l}\text { Ascocotyle (Phagicola) } \\
\text { pindoramensis }\end{array}$ & $\begin{array}{l}\text { Actinopterygii; Poeciliidae (Poecilia vivipara) } \\
\text { Behavior (Santos and Santos, 2013) }\end{array}$ & $\begin{array}{l}\text { Aves and Mammalia } \\
\text { No reports }\end{array}$ \\
\hline $\begin{array}{l}\text { Telogaster } \\
\text { opisthorchis }\end{array}$ & $\begin{array}{l}\text { Actinopterygii; Galaxiidae (Galaxias anomalus) } \\
\text { Behavior (Poulin, 1993) }\end{array}$ & $\begin{array}{l}\text { Actinoptergii; Anguilliformes } \\
\text { No reports }\end{array}$ \\
\hline $\begin{array}{l}\text { Ribeiroia } \\
\text { ondatrae }\end{array}$ & $\begin{array}{l}\text { Amphibia } \\
\text { Morphology, presumed increased predation rate (Sessions and Ruth, } \\
\text { 1990; Johnson et al., 1999, 2010) }\end{array}$ & $\begin{array}{l}\text { Aves and Mammalia } \\
\text { Local moderate inflammation (El-Dakhly et al., 2018) }\end{array}$ \\
\hline $\begin{array}{l}\text { Plagiorchis } \\
\text { noblei Park }\end{array}$ & $\begin{array}{l}\text { Insecta; Culicidae (Aedes aegypti) } \\
\text { Behavior, increased predation rate (Webber et al., 1987a,b) }\end{array}$ & $\begin{array}{l}\text { Aves and Mammalia } \\
\text { No reports }\end{array}$ \\
\hline Plagioporus sp. & $\begin{array}{l}\text { Anthozoa; Poritidae (Porites compressa) } \\
\text { Appearance, increased predation rate (Aeby, 1991) }\end{array}$ & $\begin{array}{l}\text { actinopterygii } \\
\text { No reports }\end{array}$ \\
\hline $\begin{array}{l}\text { Crassiphiala } \\
\text { bulboglossa }\end{array}$ & $\begin{array}{l}\text { Actinopterygii; Fundulidae (Fundulus diaphanous) } \\
\text { Behavior (Krause and Godin, 1994) }\end{array}$ & $\begin{array}{l}\text { Aves } \\
\text { No reports }\end{array}$ \\
\hline $\begin{array}{l}\text { Diplostomum } \\
\text { spathaceum }\end{array}$ & $\begin{array}{l}\text { Actinopterygii } \\
\text { Behavior (Crowden and Broom, 1980; Seppälä et al., 2004, 2008) }\end{array}$ & $\begin{array}{l}\text { Aves } \\
\text { No reports }\end{array}$ \\
\hline $\begin{array}{l}\text { Gymnophallus } \\
\text { fossarum }\end{array}$ & $\begin{array}{l}\text { Mollusca; Bivalvia (Venerupis aurea) } \\
\text { Positioning, increased predation rate (Combes, 2001) }\end{array}$ & $\begin{array}{l}\text { Aves; Haematopodidae (Haematopus ostralegus) } \\
\text { No reports }\end{array}$ \\
\hline $\begin{array}{l}\text { Gynaecotyla } \\
\text { aduncta }\end{array}$ & $\begin{array}{l}\text { Crustacea; Amphipoda (Corophium volutator) } \\
\text { Behavior (Damsgaard et al., 2005) }\end{array}$ & $\begin{array}{l}\text { Aves; Scolopacidae (Calidris pusilla) } \\
\text { No reports }\end{array}$ \\
\hline
\end{tabular}


TABLE 1 | Continued

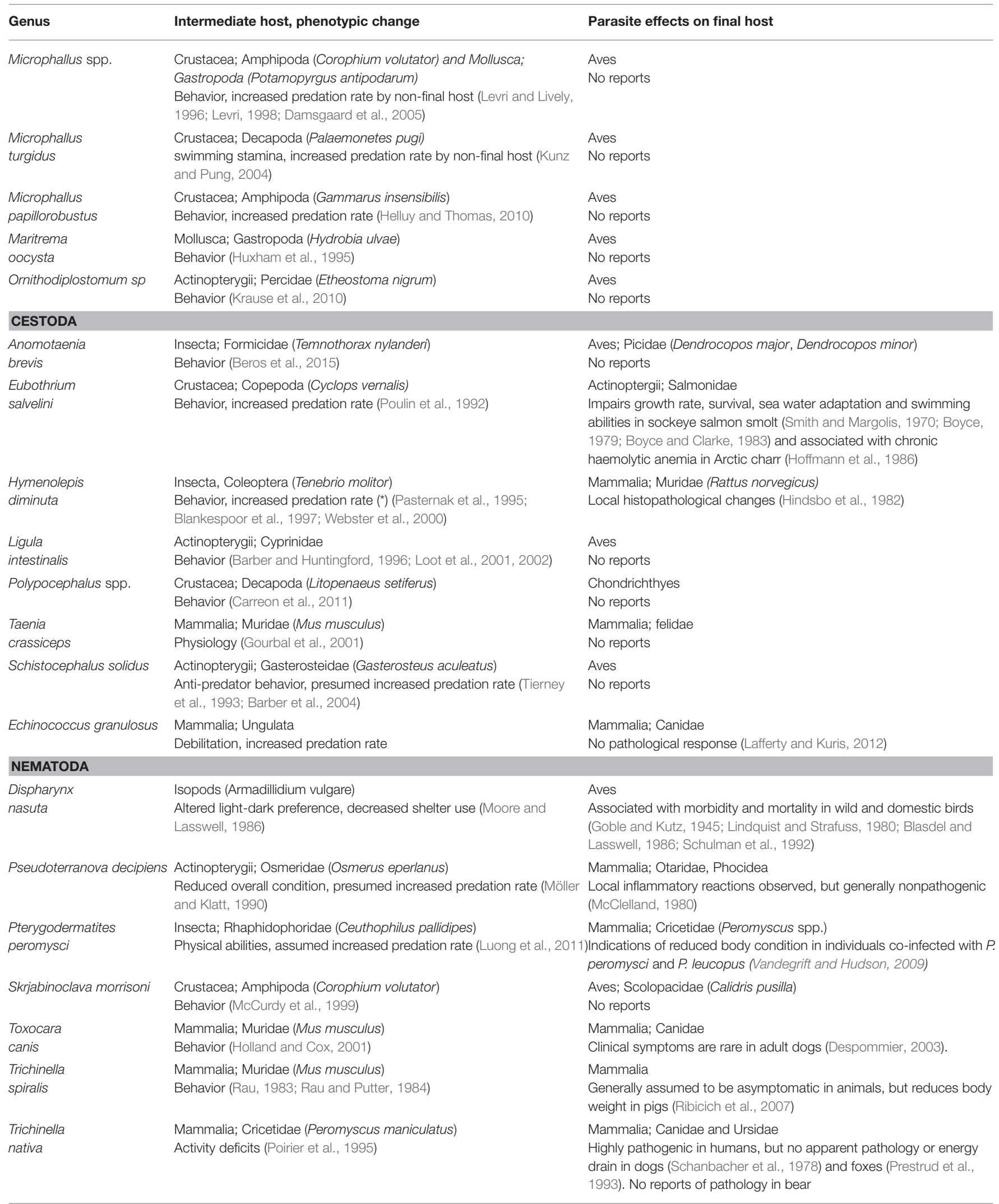


TABLE 1 | Continued

\begin{tabular}{|c|c|c|}
\hline \multicolumn{3}{|l|}{ PROTOZOA } \\
\hline Frenkelia spp. & $\begin{array}{l}\text { Mammalia; Cricetidae } \\
\text { Increased predation risk (Voríšek et al., 1998) }\end{array}$ & $\begin{array}{l}\text { Aves; Accipitriformes (Buteo spp.) } \\
\text { No reports }\end{array}$ \\
\hline $\begin{array}{l}\text { Sarcocystis } \\
\text { dispersa }\end{array}$ & $\begin{array}{l}\text { Mammalia; Muridae (Mus musculus) } \\
\text { Increased predation risk (Voríšek et al., 1998) }\end{array}$ & $\begin{array}{l}\text { Aves; Strigidae (Asio otus) } \\
\text { No reports }\end{array}$ \\
\hline Sarcocystis rauschorum & $\begin{array}{l}\text { Mammalia; Cricetidae } \\
\text { Increased exploratory activity (Quinn et al., 1987) }\end{array}$ & $\begin{array}{l}\text { Aves; Strigidae (Nyctea scandica) } \\
\text { No reports }\end{array}$ \\
\hline $\begin{array}{l}\text { Toxoplasma } \\
\text { gondii }\end{array}$ & $\begin{array}{l}\text { Mammalia; Muridae } \\
\text { Anti-predator behavior, presumed increased predation rate (Webster, } \\
\text { 2001) }\end{array}$ & $\begin{array}{l}\text { Mammalia; Felidae } \\
\text { Infection in adult feline definitive hosts are most commonly } \\
\text { asymptomatic and apparently innocuous (Elmore et al., 2010) }\end{array}$ \\
\hline \multicolumn{3}{|l|}{ APICOMPLEXA } \\
\hline $\begin{array}{l}\text { Sarcocystis } \\
\text { cernae }\end{array}$ & $\begin{array}{l}\text { Mammalia; Cricetidae (Microtus arvalis) } \\
\text { Increased predation rate (Hoogenboom and Dijkstra, 1987) }\end{array}$ & $\begin{array}{l}\text { Aves; Falconidae (Falco tinnunculus) } \\
\text { No reports }\end{array}$ \\
\hline
\end{tabular}

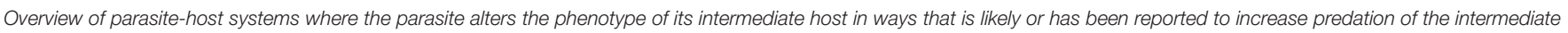
host by the final host and where the intermediate host is assumed to be energetically significant prey for the final host.

(Kuris, 2003), and in which the host actually benefits from interaction with the parasite have been proposed by several authors (Lafferty, 1992; Thomas et al., 2000). Lafferty (1992) proposed a model that weighed energetic costs of parasitism for a predator against the energetic value of infected prey items, which revealed that there is often no selective pressure to avoid parasitized prey. In other words, predators may actually benefit from their parasites if energetic costs of parasitism are moderate and prey capture is facilitated by parasites. Such hosts are likely to be under strong selection to avoid colonization by some, but not all, parasites.

Numerous reports have documented that parasite infected animals may change their behavior in ways that increase parasite fitness [e.g., Holmes and Bethel, 1972; Barber et al., 2000; Poulin, 2010; Lafferty and Shaw, 2013; Moore, 2013]. Following empirical demonstrations that amphipods harboring larval acanthocephalan parasites display behavior and abnormal coloration making them more susceptible to predation by the parasite's next host (Hindsbo, 1972; Holmes and Bethel, 1972), there has been sustained interest in this phenomenon. As a result, host manipulation by parasites has now been documented in a few hundred distinct host-parasite associations spanning all major phyla of living organisms (see reviews in Moore, 2002, 2013; Dawkins, 2012). Remarkable examples include "suicidal" behavior in rats infected by the protozoan parasite Toxoplasma gondii, which become attracted to cat urine (Berdoy et al., 2000), and water-seeking behavior in otherwise terrestrial crickets which allow parasitic hairworms to emerge and reproduce in water (Thomas et al., 2002). Interest in this field has taken a leap as new molecular and systems biology approaches are revealing the potential impact of parasites and pathogens on behavior and neurobiology both in natural ecosystems and in the human society (Biron et al., 2006; Lefèvre et al., 2009; Prandovszky et al., 2011; Biron and Loxdale, 2013; Flegr, 2015; Syn et al., 2018).

In the following we will focus on trophically transmitted parasites, which are associated with altered behavior, appearance, or general condition of prey hosts in ways that increase their rates of consumption by predatory final hosts (see reviews by Moore, 2002; Lefèvre et al., 2009; Lafferty and Shaw, 2013). In such cases, increased predation success per effort for the final host may imply a fitness advantage, given that the cost of parasitism is low. Such cases are of particular interest for the evolution of tolerance vs. pathogenicity (Kuris, 2003). To our knowledge, however, no systematic review exists that specifically investigates if parasites that are benign to the predatory host outnumber pathogenic ones among known examples of parasite mediated trophic transmission.

As will be proposed in this review, in such cases there also exists a selection pressure for minimizing the immune response to ward off beneficial infections. This stance is derived from those cases where an energetic benefit to the final host has been either demonstrated or strongly incurred by empirical data on catchability or behavior of infected prey. In an extensive review, Lafferty and Shaw (2013) identified 55 genera of trophically transmitted parasites meeting this criterion distributed among the following taxa: protozoans, acanthocephalans, nematodes, and digenean and cestode species in the platyhelminthes phylum. In the present paper, we aimed to investigate if any significant pathology has been reported among final hosts in at least one example from each of these genera. In addition, Poulin and Maure (2015) identified 26 host-parasite species combinations for which actual predation tests had been performed, which all were included. We however omit examples involving the ingestion of organisms that cannot be considered as normally occurring energetically significant prey in the diet of the end host.

For example, our criteria exclude some spectacular and wellknown examples of host manipulation. The antennae of snails infected with Leucochloridium trematodes become abnormally large and conspicuous to avian final hosts of the parasite. Snails do, however, not belong to the final host's normal diet and cannot be considered energetically important to the predatory bird (Moore, 2002). Along the same lines, ants infected by the liver fluke Dicrocoelium dendriticum climb and anchor themselves to the top of grass, presumably rendering them more susceptible to ingestion by large herbivorous mammals where the fluke can reach adulthood. Evidently, Dicrocelium metacercaria are associated with a dramatic behavioral change in the ants, but the insects are not of any known nutritional value to the ruminant 
host. Interestingly, the Dicrocoelium example provides a case where host manipulation is associated with significant pathology in the final host, i.e., the disease known as dicrocoeliosis in ruminants (Otranto and Traversa, 2003). As a contrary example from a by now classical model system, cystacanths of the acantocephalon Plagiorhynchus cylindraceus alters sheltering and light-dark preference in isopods rendering them more prone to capture by birds. Effects of adult $P$. cylindraceus on the model host, starlings, are however reported to be typically minor (Moore, 1983b; Moore and Bell, 1983a; Connors and Nickol, 1991). Although some metabolic cost may be incurred (Connors and Nickol, 1991), tissue damage is minimal, and infected birds in the wild exhibit weights comparable to those of uninfected conspecifics (Moore and Bell, 1983a). Pathological reactions are on the other hand common among unintended hosts and in vector borne and direct life cycles. In Table 1 we list the trophic transmission model systems that we identified as relevant in this context, and whether or not any associated pathology have been reported in the final host.

Of note, host modification does not necessarily need to include only strictly defined behavioral manipulation. The larval tapeworm Echinococcus granulosus for instance incapacitate ungulate intermediate hosts, such as moose by lodging in the lungs and other organs making it easier for wolves to attack the debilitated prey (Joly and Messier, 2004). The result for the end host is the same as with behavioral manipulation, the prey becomes easier to catch. In fact, mathematical models has been published which identify potential situations where wolves could not persist on moose as prey without the assistance of the debilitating parasite (Hadeler and Freedman, 1989). At least it seems likely that presence of the tapeworm enables wolves to drive the moose population to lower levels than would otherwise be possible. Canid final hosts, however, show no pathological responses to the adult tapeworm (Lafferty and Kuris, 2012).

In general, going through the literature on model systems where parasites presumably provide an easy meal to their final host by manipulating their prey (Table 1), it is curious to note the lack of reports on pathology in final hosts. In examples where reports on pathology do exist, local and moderate histopathological changes are described. In a very few cases parasitism appears to affect growth and condition of the final host (Boyce, 1979; Vandegrift and Hudson, 2009; Sheath, 2016). Even in these cases pathological effects are primarily reported in either non-preferred (Sheath, 2016) or very young (Boyce, 1979) final hosts, or with co-infections of other parasites so that causality between parasite species and host effects cannot easily be established (Vandegrift and Hudson, 2009). There are also cases in our literature review where parasitism is potentially lethal. For example, the nematode Dispharynx nasuta is associated with morbidity and mortality in several bird species that can serve as final hosts for the parasite (Goble and Kutz, 1945; Lindquist and Strafuss, 1980; Blasdel and Lasswell, 1986). It can, however, be debated whether the intermediate host in this case, the isopod Armadillidium vulgare, represent an energetically important food item for these birds. Nonetheless, there are exceptions to the rule that parasites providing easy prey are non-pathogenic to and not fiercely resisted by the final host, but the general trend appears to be one of benign tolerance.

Also of note, severity of pathology and mortality appears to be highly parasite density-dependent. Often, pathology is only observed with heavy infection load and moderate infections appears to be of little pathological consequence (Mazzi and Bakker, 2003; Teimoori et al., 2011). For instance, Hindsbo et al. (1982) found that immunological responses of rats to the cestode Hymenolepis diminuta are dose-dependent, indicating that the rodents tolerate a certain number of adult cestodes (up to 100 worms) before they mount an immune response. The underlying mechanisms behind such dose-dependent infection tolerance are unknown, but in the context of this review, it is tempting to point out that $H$. diminuta apparently provide easy to capture beetle prey for the rat final hosts. Said hosts may therefore have evolved to tolerate moderate or even substantial infection loads, ensuring survival of prey-providing parasites.

Of note, one parasite taxon appears to provoke more harm to their final host than the other taxa investigated here. In general, acanthocephalans only cause localized pathology in the gut of their hosts, but there are some reports of severe pathology. The severity of damage acanthocephalans cause to their hosts and intensity of host reactions appears to depend on the depth of proboscis penetration, the density of worm burdens and even on the systematic affiliation of the parasites and hosts (Taraschewski, 2000). Of note, those acantocephalan species that are reported to be most intensely pathogenic to their final host are not among the prey providers identified in Table $\mathbf{1}$ (for extensive review on pathogenicity of acantacephalans see Taraschewski, 2000).

\section{EXTENDING THE EXTENDED PHENOTYPE CONCEPT}

The "extended phenotype" concept promoted by Richard Dawkins implies that parasites have evolved means to alter host phenotype in ways that benefit the parasite. Increased parasite fitness has been seen as the main evolutionary driver. For instance, Poulin (2010) states "In a nutshell, host manipulation by parasite can be defined as any alteration in host phenotype, induced by a parasite that has fitness benefits for the parasite." Even Dawkins (in the editorial introduction to the 2012 book "Host Manipulation by Parasites") proclaims that the parasite is "... manipulating the behavior of its host-subverting it to the benefit of the parasite in ways that arouse admiration for the subtlety, and horror at the ruthlessness, in equal measure" (Dawkins, 2012). Presently, we will raise the proposition that in cases of parasite-mediated trophic transmission the possibility that the energetic benefit of the final host (e.g., a fish eating bird) is an equally or perhaps more important evolutionary driver (see Figure 1).

As seen above, compared to parasitized intermediate hosts that suffer increased morbidity, such as parasitic castration (Baudoin, 1975), or mortality [e.g., by predation Lafferty and Morris, 1996], reports on negative effects on intended 


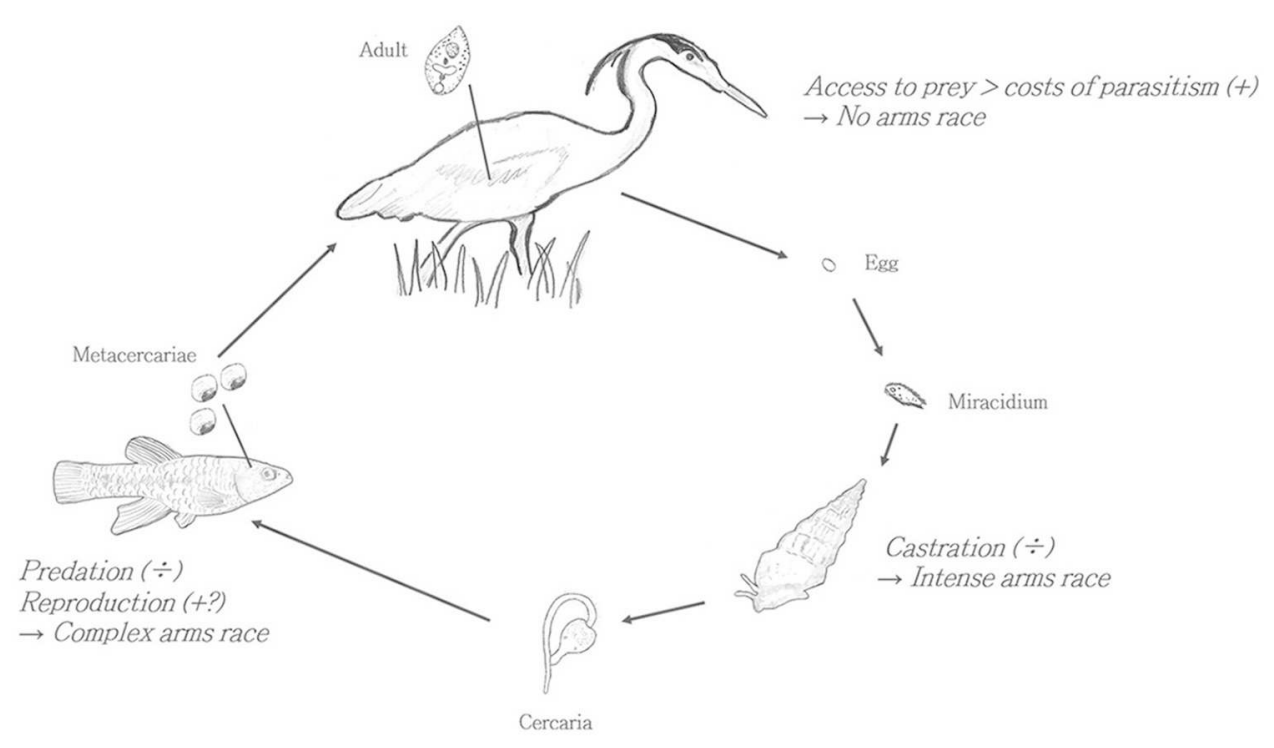

FIGURE 1 | Hypothesis: Whether a parasite is beneficial or adverse for any given host, and thus the direction of immune systems evolution, depends on host phenotype changes throughout the lifecycle. The Euhaplorchis Californiensis model system.

definitive hosts are suspiciously absent. Previous authors have also suggested that this appears to be a general trend in trophic transmission (Bailey, 1975; Geraci and St. Aubin, 1987). Moreover, definitive hosts of many trophically transmitted parasites do not appear to avoid parasitized prey (Bairagi and Adak, 2015). On the contrary, predatory definitive hosts often consume disproportionately larger numbers of infected vs. uninfected individuals (Hudson et al., 1992, 1998; Lafferty and Morris, 1996; McCallum et al., 2005). For example, F. parvipinnis infected with E. californiensis display conspicuous swimming behaviors, rendering them up to 30 times more likely to be eaten by a final bird host where the parasite completes its life cycle and sexually reproduce (Lafferty and Morris, 1996). Similarly, loss of the innate aversion to cat odor in rodents infected with Toxoplasma gondii, presumably makes them more susceptible to predation by the parasite's final feline host (Webster, 2001). Whereas, T. gondii infection in adult cats is most commonly asymptomatic and considered innocuous (Elmore et al., 2010), preliminary data from our lab indicate no energetic or physiological cost of E. californiensis in bird hosts (unpublished data). In conclusion, decreased antipredator behavior of parasitized intermediate hosts/prey, or even pro-predator behavior in some cases can fulfill the extended phenotype not only of the parasite but that of the predatory definite host.

\section{PREY PROVIDERS REVOKE THE EVOLUTIONARY ARMS RACE}

Common for the end hosts in these examples is that they do not appear to suffer the same deleterious consequences of the parasite infection as the intermediate hosts. Seen from the parasite's perspective, kindness to the final host vs. aggressive utilization of host resources could be advantageous for several reasons, in that enhanced host longevity would maximize parasite lifetime accumulated fitness. It is therefore reasonable to assume that trophically transmitted parasites could have a selective benefit from reducing their negative impact on the final host. But on the other hand, parasite mediated trophic transmission of energetically important prey is also likely to prevent the development of potentially destructive immune responses in the host, in addition to avoiding that the predatory final host evolves a tendency to avoid parasitized prey. If easily captured parasitized prey in this way fulfills the extended phenotype of not only the parasite awaiting transmission, but also that of the predator, there should be little or no selection on final hosts to minimize parasite infections. We have by no means covered an extensive list of all parasite-mediated trophic transmissions in this review, but the picture that emerges is that some predators employ parasites as a weapon in biological warfare against their prey, rather than suffering from infection in the traditional sense. This raises a pertinent question: How does the continuously developing immune system of a predatory host acquire and maintain the ability to distinguish useful helpers from pure plague? Apart from novel understanding of evolutionary drivers of host-parasite relationships, proximate understanding of these principles could potentially provide clues to combatting overactivation and resulting immunopathologies.

\section{AUTHOR CONTRIBUTIONS}

$\varnothing \varnothing$ and IBJ provided equally direct and intellectual contribution to this work, and approved the present version for publication.

\section{FUNDING}

Research Council of Norway. Project No: 250048 and 240116/F20. 


\section{REFERENCES}

Aeby, G. S. (1991). Behavioral and ecological relationships of a parasite and its hosts within a coral reef system. Pac. Sci. 45, 263-269.

Allen, J. E., and Maizels, R. M. (2011). Diversity and dialogue in immunity to helminths. Nat. Rev. Immunol. 11, 375-388. doi: 10.1038/nri2992

Anderson, R. M., and May, R. M. (1992). Infectious Diseases of Humans: Dynamics and Control. Oxford: Oxford University Press.

Ashby, B., and King, K. C. (2017). Friendly foes: the evolution of host protection by a parasite. Evol. Lett. 1, 211-221. doi: 10.1002/evl3.19

Auld, S. K., and Tinsley, M. C. (2015). The evolutionary ecology of complex lifecycle parasites: linking phenomena with mechanisms. Heredity (Edinb). 114, 125-132. doi: 10.1038 /hdy.2014.84

Bailey, G. N. A. (1975). Energetics of a host-parasite system: a preliminary report. Int. J. Parasitol. 5, 609-613. doi: 10.1016/0020-7519(75)90059-4

Bairagi, N., and Adak, D. (2015). Complex dynamics of a predator-preyparasite system: an interplay among infection rate, predator's reproductive gain and preference. Ecol. Complex 22, 1-12. doi: 10.1016/j.ecocom. 2015.01.002

Bakker, T. C. M., Mazzi, D., and Zala, S. (1997). Parasite-induced changes in behavior and color make Gammarus pulex more prone to fish predation. Ecology 78, 1098-1104. doi: 10.1890/0012-9658(1997)078[1098:PICI BA]2.0.CO;2

Barber, I., Hoare, D., and Krause, J. (2000). Effects of parasites on fish behaviour: a review and evolutionary perspective. Rev. Fish Biol. Fisher 10, 131-165. doi: 10.1023/A:1016658224470

Barber, I., and Huntingford, F. A. (1996). Parasite infection alters schooling behaviour: deviant positioning of helminth-infected minnows in conspecific groups. Proc. R. Soc. Lond. B 263, 1095-1102. doi: 10.1098/rspb.1996.0161

Barber, I., Svensson, P. A., and Walker, P. (2004). Behavioural responses to simulated avian predation in female three spined sticklebacks: the effect of experimental Schistocephalus solidus infections. Behaviour 141:1425. doi: $10.1163 / 1568539042948231$

Baudoin, M. (1975). Host castration as a parasitic strategy. Evolution 29, 335-352. doi: 10.1111/j.1558-5646.1975.tb00213.x

Benesh, D. P., Valtonen, E. T., and Seppälä, O. (2008). Multidimensionality and intra-individual variation in host manipulation by an acanthocephalan. Parasitology 135, 617-626. doi: 10.1017/S0031182008004216

Berdoy, M., Webster, J. P., and Macdonald, D. W. (2000). Fatal attraction in rats infected with Toxoplasma gondii. Proc. R. Soc. B: Biol. Sci. 267, 1591-1594. doi: 10.1098/rspb.2000.1182

Beros, S., Jongepier, E., Hagemeier, F., and Foitzik, S. (2015). The parasite's long arm: a tapeworm parasite induces behavioural changes in uninfected group members of its social host. Proc. R. Soc. B: Biol. Sci. 282:20151473. doi: $10.1098 / \mathrm{rspb} .2015 .1473$

Bethel, W. M., and Holmes, J. C. (1973). Altered evasive behavior and responses to light in amphipods harboring acanthocephalan cystacanths. J. Parasitol. 59, 945-956. doi: $10.2307 / 3278623$

Bethel, W. M., and Holmes, J. C. (1977). Increased vulnerability of amphipods to predation owing to altered behavior induced by larval acanthocephalans. Can. J. Zool. 55, 110-115. doi: 10.1139/z77-013

Betts, A., Rafaluk, C., and King, K. C. (2016). Host and parasite evolution in a tangled bank. Trends Parasitol. 32, 863-873. doi: 10.1016/j.pt.2016.08.003

Biron, D. G., and Loxdale, H. D. (2013). Host-parasite molecular cross-talk during the manipulative process of a host by its parasite. J. Exp. Biol. 216, 148-160. doi: $10.1242 /$ jeb. 073825

Biron, D. G., Ponton, F., Marché, L., Galeotti, N., Renault, L., Demey-Thomas, E., et al. (2006). 'Suicide' of crickets harbouring hairworms: a proteomics investigation. Insect Mol. Biol. 15, 731-742. doi: 10.1111/j.1365-2583.2006.00671.x

Blankespoor, C., Pappas, P., and Eisner, T. (1997). Impairment of the chemical defence of the beetle, Tenebrio molitor, by metacestodes (cysticercoids) of the tapeworm, Hymenolepis diminuta. Parasitology 115, 105-110. doi: 10.1017/S0031182097008901

Blasdel, T., and Lasswell, J. (1986). "Dispharynx nasuta in the Houston zoological gardens bird collection," in Proceedings of the Annual Meeting of the American Association of Zoo Veterinarians (Chicago, IL), 101-102.
Boyce, N. (1979). Effects of Eubothrium salvelini (Cestoda: Pseudophyllidea) on the growth and vitality of sockeye salmon, Oncorhynchus nerka. Can. J. Zool. 57, 597-602. doi: 10.1139/z79-070

Boyce, N. P., and Clarke, W. C. (1983). Eubothrium salvelini (Cestoda: Pseudophyllidea) impairs seawater adaptation of migrant Sockeye salmon Yearlings (Oncorhynchus nerka) from Babine lake, British Columbia. Can. J. Fish. Aquat. Sci. 40, 821-824. doi: 10.1139/f83-108

Brockhurst, M. A., Chapman, T., King, K. C., Mank, J. E., Paterson, S., and Hurst, G. D. (2014). Running with the Red Queen: the role of biotic conflicts in evolution. Proc. R. Soc. B: Biol. Sci. 281:20141382. doi: 10.1098/rspb.2014.1382

Brommer, J. E. (2004). Immunocompetence and its costs during development: an experimental study in blue tit nestlings. Proc. R. Soc. B: Biol. Sci. 271(Suppl. 3), S110-S113. doi: 10.1098/rsbl.2003.0103

Bullock, W. L. (1963). Intestinal histology of some salmonid fishes with particular reference to the histopathology of acanthocephalan infections. J. Morphol. 112, 23-44. doi: 10.1002/jmor.1051120104

Camp, J. W., and Huizinga, H. W. (1979). Altered color, behavior and predation susceptibility of the isopod Asellus intermedius infected with Acanthocephalus dirus. J. Parasitol. 65, 667-669. doi: 10.2307/3280340

Carney, W. P. (1969). Behavioral and morphological changes in carpenter ants harboring dicrocoeliid metacercariae. Am. Midl. Nat. 82, 605-611. doi: $10.2307 / 2423801$

Carreon, N., Faulkes, Z., and Fredensborg, B. L. (2011). Polypocephalus sp. infects the nervous system and increases activity of commercially harvested white shrimp (Litopenaeus setiferus). J. Parasitol. 97, 755-759. doi: 10.1645/GE-2749.1

Combes, C. (2001). Parasitism: The Ecology and Evolution of Intimate Interactions. Chicago, IL: University of Chicago Press.

Connors, V. A., and Nickol, B. B. (1991). Effects of Plagiorhynchus cylindraceus (Acanthocephala) on the energy metabolism of adult starlings, Sturnus vulgaris. Parasitology 103, 395-402. doi: 10.1017/S0031182000059916

Crowden, A., and Broom, D. (1980). Effects of the eyefluke, Diplostomum spathaceum, on the behaviour of dace (Leuciscus leuciscus). Anim. Behav. 28, 287-294. doi: 10.1016/S0003-3472(80)80031-5

Damsgaard, J. T., Mouritsen, K. N., and Jensen, K. T. (2005). Surface activity of Corophium volutator: a role for parasites? J. Sea Res. 54, 176-184. doi: 10.1016/j.seares.2005.04.001

Dawkins, R. (2012). "Foreword," in Host Manipulation by Parasites, eds. D. P. Hughes, J. Brodeur, and F. Thomas (Oxford: Oxford University Press), xi-xiii.

Decaestecker, E., Gaba, S., Raeymaekers, J. A., Stoks, R., Van Kerckhoven, L., Ebert, D., et al. (2007). Host-parasite 'Red Queen' dynamics archived in pond sediment. Nature 450: 870. doi: 10.1038/nature06291

Despommier, D. (2003). Toxocariasis: clinical aspects, epidemiology, medical ecology, and molecular aspects. Clin. Microbiol. Rev. 16, 265-272. doi: 10.1128/CMR.16.2.265-272.2003

Dianne, L., Bollache, L., Lagrue, C., Franceschi, N., and Rigaud, T. (2012). Larval size in acanthocephalan parasites: Influence of intraspecific competition and effects on intermediate host behavioural changes. Parasit. Vector 5, 166-166. doi: 10.1186/1756-3305-5-166

Dianne, L., Perrot-Minnot, M. J., Bauer, A., Gaillard, M., Léger, E., and Rigaud, T. (2011). Protection first then facilitation: a manipulative parasite modulates the vulnerability to predation of its intermediate host according to its own developmental stage. Evolution 65, 2692-2698. doi: 10.1111/j.1558-5646.2011.01330.x

Dunne, D. W., and Cooke, A. (2005). A worm's eye view of the immune system: consequences for evolution of human autoimmune disease. Nat. Rev. Immunol. 5, 420-426. doi: 10.1038/nri1601

El-Dakhly, K. M., Hussein, N., and El-Nahass, E.-S. (2018). Occurrence of helminths in the great cormorants, Phalacrocorax carbo, in Qena, Egypt. J. Adv. Vet. Res. 8, 6-11.

Elmore, S. A., Jones, J. L., Conrad, P. A., Patton, S., Lindsay, D. S., and Dubey, J. P. (2010). Toxoplasma gondii: epidemiology, feline clinical aspects, and prevention. Trends Parasitol. 26, 190-196. doi: 10.1016/j.pt.2010.01.009

Ewald, P. W. (1987). Transmission modes and evolution of theparasitismmutualism continuuma. Ann. N.Y. Acad. Sci. 503, 295-306. doi: 10.1111/j.1749-6632.1987.tb40616.x

Ewald, P. W. (1995). The evolution of virulence: a unifying link between parasitology and ecology. J. Parasitol. 81, 659-669. doi: 10.2307/3283951 
Flegr, J. (2015). "Host manipulation by Toxoplasma gondii," in Host Manipulations by Parasites and Viruses, ed. H. Mehlhorn (Basel: Springer International Publishing), 91-99. doi: 10.1007/978-3-319-22936-2_6

Geraci, J. R., and St. Aubin, D. J. (1987). Effects of parasites on marine mammals. Int. J. Parasitol. 17, 407-414. doi: 10.1016/0020-7519(87)90116-0

Goble, F. C., and Kutz, H. (1945). The genus Dispharynx (Nematoda: Acuariidae) in galliform and passeriform birds. J. Parasitol. 31, 323-331. doi: $10.2307 / 3273088$

Gonzalez, S. T. (2016). Influence of a trematode parasite (Microphallus turgidus) on grass shrimp (Palaemonetes pugio) response to refuge and predator presence. J. Parasitol. 102, 646-649. doi: 10.1645/15-889

Gopko, M., Mikheev, V. N., and Taskinen, J. (2015). Changes in host behaviour caused by immature larvae of the eye fluke: evidence supporting the predation suppression hypothesis. Behav. Ecol. Sociobiol. 69, 1723-1730. doi: 10.1007/s00265-015-1984-z

Gourbal, B. E., Righi, M., Petit, G., and Gabrion, C. (2001). Parasite-altered host behavior in the face of a predator: manipulation or not? Parasitol. Res. 87, 186-192. doi: 10.1007/PL00008573

Graham, A. L., Allen, J. E., and Read, A. F. (2005). Evolutionary causes and consequences of immunopathology. Annu. Rev. Ecol. Evol. Syst. 36, 373-397. doi: 10.1146/annurev.ecolsys.36.102003.152622

Gustafsson, L., Nordling, D., Andersson, M. S., Sheldon, B. C., and Qvarnström, A. (1994). Infectious diseases, reproductive effort and the cost of reproduction in birds. Philos. Trans. R. Soc. Lond. Ser. B Biol. Sci. 346, 323-331. doi: 10.1098/rstb.1994.0149

Hadeler, K. P., and Freedman, H. I. (1989). Predator-prey populations with parasitic infection. J. Math. Biol. 27, 609-631. doi: 10.1007/BF00276947

Hall, A. R., Scanlan, P. D., Morgan, A. D., and Buckling, A. (2011). Host-parasite coevolutionary arms races give way to fluctuating selection. Ecol. Lett. 14, 635-642. doi: 10.1111/j.1461-0248.2011.01624.x

Hammerschmidt, K., Koch, K., Milinski, M., Chubb, J. C., and Parker, G. A. (2009). When to go: optimalization of host switching in parasites with complex life cycles. Evolution 63, 1976-1986. doi: 10.1111/j.1558-5646.2009.00687.x

Hechtel, L. J., Johnson, C. L., and Juliano, S. A. (1993). Modification of antipredator behavior of Caecidotea intermedius by its parasite Acanthocephalus dirus. Ecology 74, 710-713. doi: 10.2307/1940798

Helluy, S., and Thomas, F. (2010). Parasitic manipulation and neuroinflammation: evidence from the system Microphallus papillorobustus (Trematoda)Gammarus (Crustacea). Parasit. Vectors 3:38. doi: 10.1186/1756-3305-3-38

Hindsbo, O., Andreassen, J., and Ruitenberg, J. (1982). Immunological and histopathological reactions of the rat against the tapeworm Hymenolepis diminuta and the effects of anti-thymocyte serum. Parasite Immunol. 4, 59-76. doi: 10.1111/j.1365-3024.1982.tb00420.x

Hindsbo, O. L. E. (1972). Effects of polymorphus (Acanthocephala) on colour and behaviour of Gammarus lacustris. Nature 238:333. doi: 10.1038/238333a0

Hine, P. M., and Kennedy, C. R. (1974). Observations on the distribution, specificity and pathogenicity of the acanthocephalan Pomphorhynchus laevis (Müller). J. Fish Biol. 6, 521-535. doi: 10.1111/j.1095-8649.1974.tb04569.x

Hoffmann, R., Kennedy, C., and Meder, J. (1986). Effects of Eubothrium salvelini Schrank, 1790 on Arctic charr, Salvelinus alpinus (L.), in an alpine lake. J. Fish Dis. 9, 153-157. doi: 10.1111/j.1365-2761.1986.tb00997.x

Holland, C. V., and Cox, D. M. (2001). Toxocara in the mouse: a model for parasite-altered host behaviour? J. Helminthol. 75:125. doi: 10.1079/JOH200169

Holmes, J. C., and Bethel, W. M. (1972). "Modification of intermediate host behaviour by parasites," in Behavioural Aspects of Parasite Transmission, eds E. U. Canning, and C. A. Wright (New York: Academic Press Inc.), 123-149.

Hoogenboom, I., and Dijkstra, C. (1987). Sarcocystis cernae: a parasite increasing the risk of predation of its intermediate host, Microtus arvalis. Oecologia 74, 86-92. doi: 10.1007/BF00377350

Hudson, P. J., Dobson, A. P., and Newborn, D. (1998). Prevention of population cycles by parasite removal. Science 282, 2256-2258. doi: $10.1126 /$ science.282.5397.2256

Hudson, P. J., Newborn, D., and Dobson, A. P. (1992). Regulation and stability of a free-leaving host-parasite system, Trichostrongylus tenuis in red grouse. I. Monitoring and parasite reduction experiment. J. Anim. Ecol. 61, 477-486. doi: $10.2307 / 5338$

Huxham, M., Raffaelli, D., and Pike, A. (1995). The effect of larval trematodes on the growth and burrowing behaviour of Hydrobia ulvae (gastropoda: prosobranchiata) in the Ythan estuary, north-east Scotland. J. Exp. Mar. Biol. Ecol. 185, 1-17. doi: 10.1016/0022-0981(94)00119-X

Johnson, P. T., Lunde, K. B., Ritchie, E. G., and Launer, A. E. (1999). The effect of trematode infection on amphibian limb development and survivorship. Science 284, 802-804. doi: 10.1126/science.284.5415.802

Johnson, P. T. J., Reeves, M. K., Krest, S. K., and Pinkney, A. E. (2010). “A decade of deformities: advances in our understanding of amphibian malformations and their implications," in Ecotoxicology of Amphibians and Reptiles, 2nd Edn, eds D. W. Sparling, G. Linder, C. A. Bishop, and S. K. Krest (New York, NY: SETAC Press; CRC Press), 511-536.

Joly, D. O., and Messier, F. (2004). The distribution of Echinococcus granulosus in moose: evidence for parasite-induced vulnerability to predation by wolves? Oecologia 140, 586-590. doi: 10.1007/s00442-004-1633-0

Kaldonski, N., Perrot-Minnot, M.-J., and Cézilly, F. (2007). Differential influence of two acanthocephalan parasites on the antipredator behaviour of their common intermediate host. Anim. Behav. 74, 1311-1317. doi: 10.1016/j.anbehav.2007.02.027

Kaufman, J. (2010). Evolution and immunity. Immunology 130, 459-462. doi: 10.1111/j.1365-2567.2010.03294.x

Kennedy, C., Broughton, P., and Hine, P. (1978). The status of brown and rainbow trout, Salmo trutta and S. gairdneri as hosts of the Acanthocephalan, Pomphorhynchus laevis. J. Fish Biol.13, 265-275. doi: 10.1111/j.1095-8649.1978.tb03434.x

Krause, J., and Godin, J.-G. J. (1994). Influence of parasitism on the shoaling behaviour of banded killifish, Fundulus diaphanus. Can. J. Zool. 72, 1775-1779. doi: $10.1139 / \mathrm{z} 94-240$

Krause, R. J., Grant, J. W. A., McLaughlin, J. D., and Marcogliese, D. J. (2010). Do infections with parasites and exposure to pollution affect susceptibility to predation in johnny darters (Etheostoma nigrum)? Can. J. Zool. 88, 1218-1225. doi: 10.1139/Z10-089

Kunz, A. K., and Pung, O. J. (2004). Effects of Microphallus turgidus (Trematoda: Microphallidae) on the predation, behavior, and swimming stamina of the grass shrimp Palaemonetes pugio. J. Parasitol.90, 441-445. doi: 10.1645/GE-183R

Kuris, A. M. (2003). Evolutionary ecology of trophically transmitted parasites. J. Parasitol. 89, S96-S100.

La Sala, L. F., Perez, A. M., Smits, J. E., and Martorelli, S. R. (2013). Pathology of enteric infections induced by the acanthocephalan Profilicollis chasmagnathi in Olrog's gull, Larus atlanticus, from Argentina. J. Helminthol. 87, 17-23. doi: 10.1017/S0022149X11000721

Laanto, E., Hoikkala, V., Ravantti, J., and Sundberg, L.-R. (2017). Long-term genomic coevolution of host-parasite interaction in the natural environment. Nat. Commun. 8:111. doi: 10.1038/s41467-017-00158-7

Lafferty, K. D. (1992). Foraging on prey that are modified by parasites. Am. Nat. 140, 854-867. doi: $10.1086 / 285444$

Lafferty, K. D., and Kuris, M. A. (2012). "Ecological consequences of manipulative parasites," in Host Manipulation by Parasites, eds D. P. Hughes, J. Brodeur, and F. Thomas (Oxford: Oxford University Press), 158-168.

Lafferty, K. D., and Morris, A. K. (1996). Altered behavior of parasitized killifish increases susceptibility to predation by bird final hosts. Ecology 77, 1390-1397. doi: $10.2307 / 2265536$

Lafferty, K. D., and Shaw, J. C. (2013). Comparing mechanisms of host manipulation across host and parasite taxa. J. Exp. Biol. 216(Pt 1), 56-66. doi: $10.1242 /$ jeb. 073668

Latham, A. D., and Poulin, R. (2002). Effect of acanthocephalan parasites on hiding behaviour in two species of shore crabs. J. Helminthol. 76, 323-326. doi: 10.1079/JOH2002139

Lefèvre, T., Adamo, S. A., Biron, D. G., Missè, D., Hughes, D., and Thomas, F. (2009). Invasion of the body snatchers: the diversity and evolution of manipulative strategies in host-parasite interactions. Adv. Parasitol. 68, 45-83. doi: 10.1016/S0065-308X(08)00603-9

Levine, B., Mizushima, N., and Virgin, H. W. (2011). Autophagy in immunity and inflammation. Nature 469, 323-335. doi: 10.1038/nature09782

Levri, E. P. (1998). The influence of non-host predators on parasite-induced behavioral changes in a freshwater snail. Oikos, 531-537. doi: 10.2307/3546773

Levri, E. P., and Lively, C. M. (1996). The effects of size, reproductive condition, and parasitism on foraging behaviour in a freshwater snail, Potamopyrgus antipodarum. Anim. Behav. 51, 891-901. doi: 10.1006/anbe.1 996.0093 
Libersat, F., and Moore, J. (2000). The parasite Moniliformis moniliformis alters the escape response of its cockroach host Periplaneta americana. J. Insect Behav. 13, 103-110. doi: 10.1023/A:1007719710664

Lindquist, W., and Strafuss, A. (1980). (Dispharynx nasuta) May cycle within avian zoo populations. J. Zoo Anim. Med. 11, 120-122. doi: 10.2307/20094492

Loot, G., Aulagnier, S., Lek, S., Thomas, F., and Guégan, J.-F. (2002). Experimental demonstration of a behavioural modification in a cyprinid fish, Rutilus rutilus (L.), induced by a parasite, Ligula intestinalis (L.). Can. J. Zool. 80, 738-744. doi: 10.1139/z02-043

Loot, G., Brosse, S., Lek, S., and Guégan, J. F. (2001). Behaviour of roach (Rutilus rutilus L.) altered by Ligula intestinalis (Cestoda: Pseudophyllidea): a field demonstration. Freshw. Biol. 46, 1219-1227. doi: 10.1046/j.1365-2427.2001.00733.x

Luong, L. T., Hudson, P. J., and Braithwaite, V. A. (2011). Parasite-induced changes in the anti-predator behavior of a cricket intermediate host. Ethology 117, 1019-1026. doi: 10.1111/j.1439-0310.2011.01951.x

Maizels, R. M. (2016). Parasitic helminth infections and the control of human allergic and autoimmune disorders. Clin. Microbiol. Infect. 22, 481-486. doi: 10.1016/j.cmi.2016.04.024

May, R. M., and Anderson, R. M. (1990). Parasite-host coevolution. Parasitology 100, S89-S101. doi: 10.1017/S0031182000073042

Mazzi, D., and Bakker, T. C. (2003). A predator's dilemma: prey choice and parasite susceptibility in three-spined sticklebacks. Parasitology 126, 339-347. doi: $10.1017 /$ S0031182003003019

McCallum, H., Gerber, L., and Jani, A. (2005). Does infectious disease influence the efficacy of marine protected areas? A theoretical framework. J. Appl. Ecol. 42, 688-698. doi: 10.1111/j.1365-2664.2005.01043.x

McClelland, G. (1980). Phocanema decipiens: pathology in seals. Exp. Parasitol. 49, 405-419. doi: 10.1016/0014-4894(80)90075-2

McCurdy, D. G., Forbes, M. R., and Boates, J. S. (1999). Evidence that the parasitic nematode Skrjabinoclava manipulates host corophium behavior to increase transmission to the sandpiper, Calidris pusilla. Behav. Ecol. 10, 351-357. doi: 10.1093/beheco/10.4.351

Methot, P. O., and Alizon, S. (2014). What is a pathogen? Toward a process view of host-parasite interactions. Virulence 5, 775-785. doi: 10.4161/21505594.2014.960726

Möller, H., and Klatt, S. (1990). Smelt as host of the sealworm (Pseudoterranova decipiens) in the Elbe estuary. Can. Bull. Fish. Aquat. Sci. 222, 129-138.

Moore, J. (1983a). Altered behavior in cockroaches (Periplaneta americana) infected with an archiacanthocephalan, Moniliformis moniliformis. J. Parasitol. 69, 1174-1176. doi: $10.2307 / 3280893$

Moore, J. (1983b). Responses of an avian predator and its isopod prey to an acanthocephalan parasite. Ecology 64, 1000-1015. doi: 10.2307/1937807

Moore, J. (2002). Parasites and the Behavior of Animals. Oxford: Oxford University Press.

Moore, J. (2013). An overview of parasite-induced behavioral alterations - and some lessons from bats. J. Exp. Biol. 216, 11-17. doi: 10.1242/jeb.074088

Moore, J., and Bell, D. H. (1983a). Pathology (?) of Plagiorhynchus cylindraceus in the starling, Sturnus vulgaris. J. Parasitol. 69, 387-390. doi: 10.2307/3281241

Moore, J., and Lasswell, J. (1986). Altered behavior in Isopods (Armadillidium vulgare) infected with the Nematode Dispharynx nasuta. J. Parasitol. 72, 186-189. doi: $10.2307 / 3281818$

Nordling, D., Andersson, M., Zohari, S., and Lars, G. (1998). Reproductive effort reduces specific immune response and parasite resistance. Proc. R. Soc. Lond. Ser. B Biol. Sci. 265, 1291-1298. doi: 10.1098/rspb.1998.0432

Nowak, M. A., and May, R. M. (1994). Superinfection and the evolution of parasite virulence. Proc. R. Soc. Lond. B 255, 81-89. doi: 10.1098/rspb.1994.0012

Otranto, D., and Traversa, D. (2003). Dicrocoeliosis of ruminants: a little known fluke disease. Trends Parasitol. 19, 12-15. doi: 10.1016/\$1471-4922(02) 00009-0

Parker, G. A., Ball, M. A., Chubb, J. C., Hammerschmidt, K., and Milinski, M. (2009). When should a trophically transmitted parasite manipulate its host? Evolution 63, 448-458. doi: 10.1111/j.1558-5646.2008. 00565.x

Pasternak, A. F., Huntingford, F. A., and Crompton, D. W. T. (1995). Changes in metabolism and behaviour of the freshwater copepod Cyclops strenuus abyssorum infected with Diphyllobothrium spp. Parasitology 110, 395-399. doi: $10.1017 / S 0031182000064738$
Paterson, S., Vogwill, T., Buckling, A., Benmayor, R., Spiers, A., Thomson, N. R., et al. (2010). Antagonistic coevolution accelerates molecular evolution. Nature 464:275. doi: 10.1038/nature08798

Pippy, J. H. (1969). Pomphorhynchus laevis (Zoega) Müller, 1776 (Acanthocephala) in Atlantic salmon (Salmo salar) and its use as a biological tag. J. Fish. Board Can. 26, 909-919. doi: 10.1139/f69-088

Poirier, S. R., Rau, M. E., and Wang, X. (1995). Diel locomotory activity of deer mice (Peromyscus maniculatus) infected with Trichinella nativa or Trichinella pseudospiralis. Can. J. Zool. 73, 1323-1334. doi: 10.1139/z95-156

Poulin, R. (1993). Age-dependent effects of parasites on anti-predator responses in two New Zealand freshwater fish. Oecologia 96, 431-438. doi: $10.1007 / \mathrm{BF} 00317516$

Poulin, R. (2010). "Parasite manipulation of host behavior: an update and frequently asked questions," in Advances in the Study of Behavior, eds H. J. Brockmann, T. J. Roper, M. Naguib, K. E. Wynne-Edwards, J. C. Mitani, and L. W. Simmons (London; Burlington, MA; San Diego, CA: Academic Press), 151-186. doi: 10.1016/S0065-3454(10)41005-0

Poulin, R., Brodeur, J., and Moore, J. (1994). Parasite manipulation of host behaviour: should hosts always lose? Oikos 70, 479-484. doi: 10.2307/3545788

Poulin, R., Curtis, M., and Rau, M. (1992). Effects of Eubothrium salvelini (Cestoda) on the behaviour of Cyclops vernalis (Copepoda) and its susceptibility to fish predators. Parasitology 105, 265-271. doi: 10.1017/S0031182000074199

Poulin, R., and Maure, F. (2015). Host manipulation by parasites: a look back before moving forward. Trends Parasitol. 31, 563-570. doi: $10.1016 / j . p t .2015 .07 .002$

Prandovszky, E., Gaskell, E., Martin, H., Dubey, J. P., Webster, J. P., and McConkey, G. A. (2011). The neurotropic parasite Toxoplasma gondii increases dopamine metabolism. PLoS ONE 6:e23866. doi: 10.1371/journal.pone.0023866

Prestrud, P., Stuve, G., and Holt, G. (1993). The Prevalence of Trichinella sp. in Arctic Foxes (Alopex lagopus) in Svalbard. J. Wildl. Dis. 29, 337-340. doi: 10.7589/0090-3558-29.2.337

Quinn, S. C., Brooks, R. J., and Cawthorn, R. J. (1987). Effects of the protozoan parasite Sarcocystis rauschorum on open-field behaviour of its intermediate vertebrate host, Dicrostonyx richardsoni. J. Parasitol. 73, 265-271. doi: $10.2307 / 3282077$

Rau, M. (1983). The open-field behaviour of mice infected with Trichinella spiralis. Parasitology 86, 311-318. doi: 10.1017/S0031182000050472

Rau, M. E., and Putter, L. (1984). Trichinella spiralis-infected CD-1 mice. Parasitology 89, 579-584. doi: 10.1017/S0031182000056778

Ribicich, M., Gamble, H. R., Rosa, A., Sommerfelt, I., Marquez, A., Mira, G., et al. (2007). Clinical, haematological, biochemical and economic impacts of Trichinella spiralis infection in pigs. Vet. Parasitol. 147, 265-270. doi: 10.1016/j.vetpar.2007.04.017

Rich, R. R., and Chaplin, D. D. (2019). "The human immune response," in Clinical Immunology: Principles and Practice, eds R. R. Rich, T. A. Fleisher, W. T. Shearer, H. W. Schroeder, A. J. Frew, and C. M. Weyand (Amsterdam: Elsevier), 3-17.

Sakthivel, A., Gopalakrishnan, A., and Selvakumar, P. (2016). Pathological manifestation of the Acanthocephalus dirus in Thunnus albacares. Asian Pac. J. Trop. Dis. 6, 350-353. doi: 10.1016/S2222-1808(15)61045-3

Santos, E. G., and Santos, C. P. (2013). Parasite-induced and parasite developmentdependent alteration of the swimming behavior of fish hosts. Acta Trop. 127, 56-62. doi: 10.1016/j.actatropica.2013.03.008

Schanbacher, L. M., Nations, J. K., Weisbrodt, N. W., and Castro, G. A. (1978). Intestinal myoelectric activity in parasitized dogs. Am. J. Physiol. Regul. Integr. Comp. Physiol. 234, R188-R195. doi: 10.1152/ajpregu.1978.234.5.R188

Schmidt, G. D., Walley, H. D., and Wijek, D. S. (1974). Unusual pathology in a fish due to the acanthocephalan Acanthocephalus jacksoni Bullock, 1962. J. Parasitol. 60, 730-731. doi: 10.2307/3278753

Schulman, F. Y., Montali, R. J., and Citino, S. B. (1992). Pathology, diagnosis, and treatment of Synhimantus nasuta infection in African jacanas (Actophilornis africana). J. Zoo Wildl. Med. 23, 313-317.

Seppälä, O., Karvonen, A., and Valtonen, E. T. (2004). Parasite-induced change in host behaviour and susceptibility to predation in an eye fluke-fish interaction. Anim. Behav. 68, 257-263. doi: 10.1016/j.anbehav.2003.10.021

Seppälä, O., Karvonen, A., and Valtonen, E. T. (2008). Shoaling behaviour of fish under parasitism and predation risk. Anim. Behav. 75, 145-150. doi: 10.1016/j.anbehav.2007.04.022 
Sessions, S. K., and Ruth, S. B. (1990). Explanation for naturally occurring supernumerary limbs in amphibians. J. Exp. Zool. 254, 38-47. doi: $10.1002 /$ jez.1402540107

Sheath, D. (2016). Ecological Consequences of Indigenous and Non-Indigenous Freshwater Fish Parasites. PhD thesis, Bournemouth University, Bournemouth.

Siva-Jothy, M. T., Tsubaki, Y., and Hooper, R. E. (1998). Decreased immune response as a proximate cost of copulation and oviposition in a damselfly. Physiol. Entomol. 23, 274-277. doi: 10.1046/j.1365-3032.1998.233090.x

Smith, H. D., and Margolis, L. (1970). Some effects of Eubothriuin salvelini (Schank, 1790) on Sockeye salmon, Oncorhynchus nerka (Walbaum), in Babine Lake, British Columbia. J. Parasitol. 56, 321-322.

Soler, J. J., de Neve, L., Pérez-Contreras, T., Soler, M., and Sorci, G. (2003). Trade-off between immunocompetence and growth in magpies: an experimental study. Proc. R. Soc. B: Biol. Sci. 270, 241-248. doi: 10.1098/rspb. 2002.2217

Sures, B. (2002). Competition for minerals between Acanthocephalus lucii and its definitive host perch (Perca fluviatilis). Int. J. Parasitol. 32, 1117-1122. doi: 10.1016/S0020-7519(02)00083-8

Syn, G., Anderson, D., Blackwell, J. M., and Jamieson, S. E. (2018). Epigenetic dysregulation of host gene expression in Toxoplasma infection with specific reference to dopamine and amyloid pathways. Infect. Genet. Evol. 65, 159-162. doi: 10.1016/j.meegid.2018.07.034

Taraschewski, H. (2000). Host-parasite interactions in Acanthocephala: a morphological approach. Adv. Parasitol. 46, 1-179. doi: 10.1016/S0065-308X(00)46008-2

Teimoori, S., Gharaguzlu, M., Makki, M., Shahbazi, F., Mobedi, I., Saboor Yaraghi, A., et al. (2011). Heavy worm burden of Moniliformis moniliformis in urban rats with histopathological description. Iran. J. Parasitol. 6:107.

Thomas, F., and Poulin, R. (1998). Manipulation of a mollusc by a trophically transmitted parasite: convergent evolution or phylogenetic inheritance? Parasitology 116, 431-436. doi: 10.1017/S003118209800239X

Thomas, F., Poulin, R., Guégan, J. F., Michalakis, Y., and Renaud, F. (2000). Are there pros as well as cons to being parasitized? Parasitol. Today 16, 533-536. doi: 10.1016/S0169-4758(00)01790-7

Thomas, F., Schmidt-Rhaesa, A., Martin, G., Manu, C., Durand, P., and Renaud, F. (2002). Do hairworms (Nematomorpha) manipulate the water seeking behaviour of their terrestrial hosts? J. Evol. Biol. 15, 356-361. doi: 10.1046/j.1420-9101.2002.00410.x

Tierney, J. F., Huntingford, F. A., and Crompton, D. W. (1993). The relationship between infectivity of Schistocephalus solidus (Cestoda) and antipredator behaviour of its intermediate host, the three-spined stickleback, Gasterosteus aculeatus. Anim. Behav. 46, 603-605. doi: 10.1006/anbe. 1993.1229

Vandegrift, K. J., and Hudson, P. J. (2009). Could parasites destabilize mouse populations? The potential role of Pterygodermatites peromysci in the population dynamics of free-living mice, Peromyscus leucopus. Int. J. Parasitol. 39, 1253-1262. doi: 10.1016/j.ijpara.2009.02.025

Voríšek, P., Votýpka, J., Zvára, K., and Svobodová, M. (1998). Heteroxenous coccidia increase the predation risk of parasitized rodents. Parasitology 117, 521-524. doi: 10.1017/S0031182098003242

Wanstall, S., Robotham, P., and Thomas, J. (1986). Pathological changes induced by Pomphorhynchus laevis Müller (Acanthocephala) in the gut of rainbow trout, Salmo gairdneri Richardson. Zeitschrift für Parasitenkunde 72, 105-114. doi: 10.1007/BF00927741

Webber, R., Rau, M., and Lewis, D. (1987a). The effects of Plagiorchis noblei (Trematoda: Plagiorchiidae) matacercariae on the susceptibility of Aedes aegypti larvae to predation by guppies (Poecilia reticulata) and meadow voles (Microtus pennsylvanicus). Can. J. Zool. 65, 2346-2348. doi: 10.1139/z87-353

Webber, R., Rau, M., and Lewis, D. (1987b). The effects of Plagiorchis noblei (Trematoda: Plagiorchiidae) metacercariae on the behavior of Aedes aegypti larvae. Can. J. Zool. 65, 1340-1342. doi: 10.1139/z87-212

Webster, J., Gowtage-Sequeira, S., Berdoy, M., and Hurd, H. (2000). Predation of beetles (Tenebrio molitor) infected with tapeworms (Hymenolepis diminuta): a note of caution for the manipulation hypothesis. Parasitology 120, 313-318. doi: 10.1017/S003118209900548X

Webster, J. P. (2001). Rats, cats, people and parasites: the impact of latent toxoplasmosis on behaviour. Microbes Infect. 3, 1037-1045. doi: 10.1016/S1286-4579(01)01459-9

Weinreich, F., Benesh, D. P., and Milinski, M. (2013). Suppression of predation on the intermediate host by two trophically-transmitted parasites when uninfective. Parasitology 140, 129-135. doi: 10.1017/S0031182012 001266

Wilson, K., and Edwards, J. (1986). The effects of parasitic infection on the behaviour of an intermediate host, the American cockroach, Periplaneta americana, infected with the acanthocephalan, Moniliformis moniliformis. Anim. Behav. 34, 942-944. doi: 10.1016/S0003-3472(86)80088-4

Woolhouse, M. E. J., Webster, J. P., Domingo, E., Charlesworth, B., and Levin, B. R. (2002). Biological and biomedical implications of the co-evolution of pathogens and their hosts. Nat. Genet. 32:569. doi: 10.1038/ng1202-569

Conflict of Interest Statement: The authors declare that the research was conducted in the absence of any commercial or financial relationships that could be construed as a potential conflict of interest.

Copyright (c) 2019 Øverli and Johansen. This is an open-access article distributed under the terms of the Creative Commons Attribution License (CC BY). The use, distribution or reproduction in other forums is permitted, provided the original author(s) and the copyright owner(s) are credited and that the original publication in this journal is cited, in accordance with accepted academic practice. No use, distribution or reproduction is permitted which does not comply with these terms. 